\title{
2 軸応力下の円形空洞の弾塑性変形*
}

境界要素-特性曲線結合法による岩盤空洞の弾塑性解析(第 2 報)

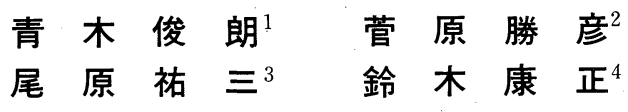

1. 緒

言

第 1 報 ${ }^{1)}$ において境界要素法と特性曲線法とを用いた弾 塑性応力解析法を提案し, 側圧比が $1 / 3$ 以上の 2 軸的な初 期応力状態における地下空洞まわりの弾塑性応力場の解析 方法として有効であることを検証した。しかし，紙面の都 合で变位場の解析法には言及できなかつた。そこで, 本論 文では第 1 報の方法による応力場の解析結果に基づいて変 位場を解析する方法をまず提案する。つぎに，これら一連 の数值解析法を円形空洞に適用し，2軸応力下の円形空洞 の弾塑性挙動を分析した結果を報告する。

\section{2. 静水圧下の円形空洞軸対称变形}

降伏条件としてモール・クーロソの破壊基準

$$
\tau=c+\sigma \tan \phi
$$

を採用する。これは主応力を用いると，

$$
\sigma_{1}=S c+q \sigma_{3}
$$

と書ける。ここに, $c$ は粘着力, $\phi$ は内部摩擦角, $S c$ は 1 軸 圧縮強さであり，次式が成立する。

$$
\begin{aligned}
& S c=2 c \tan \left(\frac{\pi}{4}+\frac{\phi}{2}\right) \\
& q=\tan ^{2}\left(\frac{\pi}{4}+\frac{\phi}{2}\right)
\end{aligned}
$$

静水圧 $\sigma_{0} \geqq \frac{1}{2} S c$ が初期応力として作用する半径 $R$ の円 形空洞まわりの塑性域 $\left(R^{*} \geqq r \geqq R\right)$ の応力状態は, Fig.1 の極座標系を用いると, 平衡方程式(5)式と降伏条件式(6)式 を連立させて, (7)式のように与えられる ${ }^{2)}$ 。

$$
\begin{aligned}
& \frac{d \sigma_{r}}{d r}=\frac{\sigma_{\theta}-\sigma_{r}}{r} \\
& \sigma_{\theta}=S c+q \sigma_{r} \\
& \sigma_{r}=\frac{S c}{1-q}\left\{1-\left(\frac{r}{R}\right)^{q-1}\right\}
\end{aligned}
$$

一方, 弾性域 $\left(r \geqq R^{*}\right)$ の応力状態は

1987 年 9 月 21 日受理

1. 正会員 東急建設 (株) 施工本部

2. 正会員 工博 能本大学教授 工学部材料開発工学科

3. 正会員 工博 熊本大学講師 工学部材料開発工学科

4. 東電設計 (株) 土木本部

$$
\begin{aligned}
& \sigma_{r}=\sigma_{0} \\
& -\frac{(q-1) \sigma_{0}+S c}{q+1}\left(\frac{R^{*}}{r}\right)^{2} \\
& \cdots \cdots \cdots(8) \\
& \sigma_{\theta}=2 \sigma_{0}-\sigma_{r} \cdots \cdots(9)
\end{aligned}
$$

で与学られる2)。すなわ ち, $r=R^{*}$ において半径 方向の応力 $\sigma_{r}$ が連続し, $R^{*}$ は次式で与えられる。

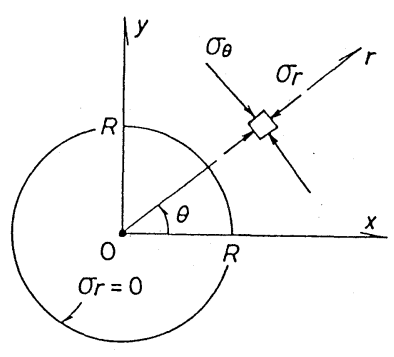

Fig. 1 A circular opening and the co-ordinates.

$$
\left(\frac{R^{*}}{R}\right)^{q-1}=\frac{2\left\{(q-1) \sigma_{0}+S_{c}\right\}}{(q+1) S c}
$$

静水圧下の変位は $r$ 方向に生じる。これを $\xi$ 書くと, 平面ひずみ状態の場合，弾性域では

$$
\frac{2 G \xi}{r}=(1-2 \nu) \sigma_{0}+\frac{(q-1) \sigma_{0}+S c}{q+1}\left(\frac{R^{*}}{r}\right)^{2}
$$

である ${ }^{2)}$ 。こに, Gは剛性率, $\nu$ はポアソン比である。(11) 式の第 1 項は初期変位場 $\xi_{0}$ を, 第 2 項は空洞開削による 変化すなわち掘削変位 $\Delta \xi$ を示す。

塑性域のひずみは弾性ひずみと塑性ひずみの和であり， 次式て定義できるものとする。

$$
\begin{aligned}
& \varepsilon_{r}=\varepsilon_{r}^{e}+\varepsilon_{r}{ }^{p}=\frac{d \xi}{d r} \\
& \varepsilon_{\theta}=\varepsilon_{\theta}{ }^{e}+\varepsilon_{\theta}{ }^{p}=\frac{\xi}{r}
\end{aligned}
$$

ここに，添字 $e$ および $p$ はそれぞれ弾性ひずみおよび塑性 びずみを示す。 $\varepsilon_{r}{ }^{p}$ および $\varepsilon_{\theta}{ }^{p}$ が常に主ひずみであること を考慮すると, 塑性ポテンシャルの理論 (関連流れ則) から,

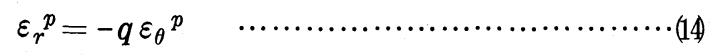

と仮定でき，(12)，(13)式よりつぎの微分方程式を得る。

$$
\frac{d \xi}{d r}+q \frac{\xi}{r}=q \varepsilon_{\theta}^{e}+\varepsilon_{r}^{e}
$$

ただし, 右辺の $\varepsilon_{r}{ }^{e}, \varepsilon_{\theta}{ }^{e}$ は平面ひずみ状態として塑性域の 応力(6), (7)式からつぎのように与えられる

$$
\begin{aligned}
& 2 G \varepsilon_{r}{ }^{e}=\frac{S c}{1-q}\left\{(1-2 \nu)-(1-\nu-q \nu)\left(\frac{r}{R}\right)^{q-1}\right\} \\
& 2 G \varepsilon_{\theta}^{e}=\frac{S c}{1-q}\left\{(1-2 \nu)-(q-\nu-q \nu)\left(\frac{r}{R}\right)^{q-1}\right\}
\end{aligned}
$$

日本鉱業会誌/104 1206 ('88-8) $489<1>$ 


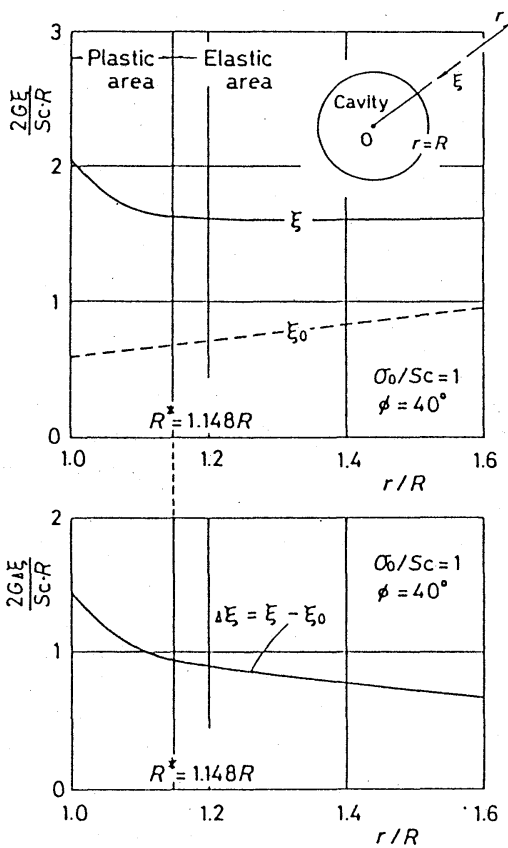

(a)

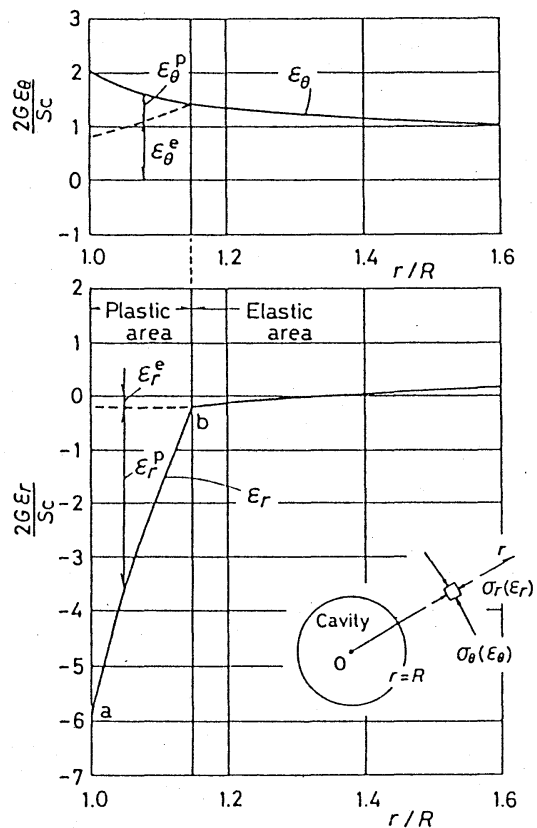

(b)

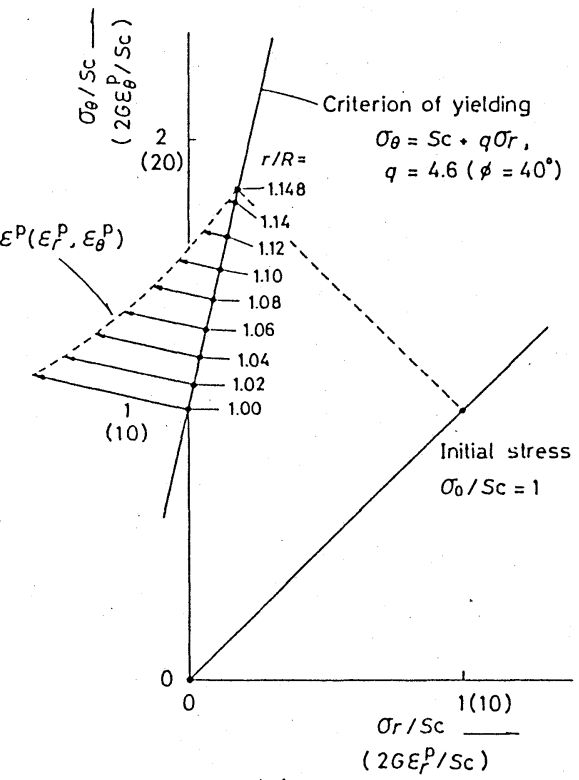

(c)

Fig. 2 Distributions of displacement and strain around circular opening under hydrostatic pressure $\sigma_{0}$ in the case of $\sigma_{0} / S c=1$ and $\phi=40^{\circ}$ : (a) total displacement $\xi$, initial displacement $\xi_{0}$ and displacement increment $\Delta \xi=\xi-\xi_{0}$; (b) radial strain $\epsilon_{r}$ and tangential strain $\epsilon_{\theta}$; (c) plastic strain components and the criterion of yielding.

したがつて, $r=R$ *における変位の連続性を考慮すると, (15)式の解として次式を得る。

$$
\begin{aligned}
\frac{2 G \xi}{r}= & \frac{S c}{1-q}\left\{(1-2 \nu)-\frac{(1-\nu)\left(q^{2}+1\right)-2 \nu q}{2 q}\left(\frac{r}{R}\right)^{q-1}\right\} \\
& +\frac{(1-\nu)\left\{(q-1) \sigma_{0}+S c\right\}}{q}\left(\frac{R^{*}}{r}\right)^{q+1} \quad \cdots \cdots \cdots(18)
\end{aligned}
$$

したがつて, 掘削変位 $\Delta \xi$ は

$$
\frac{2 G \Delta \xi}{r}=\frac{2 G \xi}{r}-(1-2 \nu) \sigma_{0}
$$

で与えられる。

Fig. 2 に解析例を示す。ただし， $\phi=40^{\circ}$ $(q=4.6)$ 抽び $\sigma_{0} / S_{c}=1.0$ を仮定した。 (10)式より塑性域外半径 $R^{*}$ は $1.148 R$ であり, 全変位 $\xi$, 初期変位 $\xi_{0}$ および掘削変位 $\Delta \xi$ $=\xi-\xi_{0}$ の分布はそれぞれFig.2(a)に示す ようである。塑性域の変位 $\xi$ および $\Delta \xi=$ $\xi-\xi_{0}$ は壁面に近づくとともに(18)式に従つ て指数関数的に増加する。これは, Fig. 2 (b)に示した塑性域における引張の塑性ひず み $\varepsilon_{r}^{p}$ の発生に原因している。Fig.2(c)に 図示するように, 塑性ひずみ $\varepsilon^{p}\left(\varepsilon_{r}^{p}, \varepsilon_{\theta}{ }^{p}\right)$ は塑性主びずみ空間の塑性ポテンシャル曲 面に対して外向き法線方向に発生する。し たがつて, 上述した引張の $\varepsilon_{r}^{p}$ は内部摩擦 角 いダイレイタンシーが発生する。

塑性域はFig.3(a)に示すようにリング状
であり，その幅 DはFig.3(b)に示すように地圧強度比 $\sigma_{0} /$ $S c$ とともに増加し, 内部摩擦角 $\phi$ に反比例する。これに対 応して, 空洞開削に伴う壁面変位 $\Delta \xi a t r=R$ はFig.3(c)

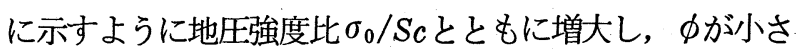
いほど大きい。しかし， фが大きいほど塑性域におけるダ イレイタンシーが著しくなるために, 図示した地圧強度比 の範囲においては, $\phi に よ る \Delta \xi の$ 相違はわずかである。し たがつて, 関連流れ則に従うとき, 壁面変位 $\Delta \xi$ は主として 地圧強度比に支配されると結論できよう。
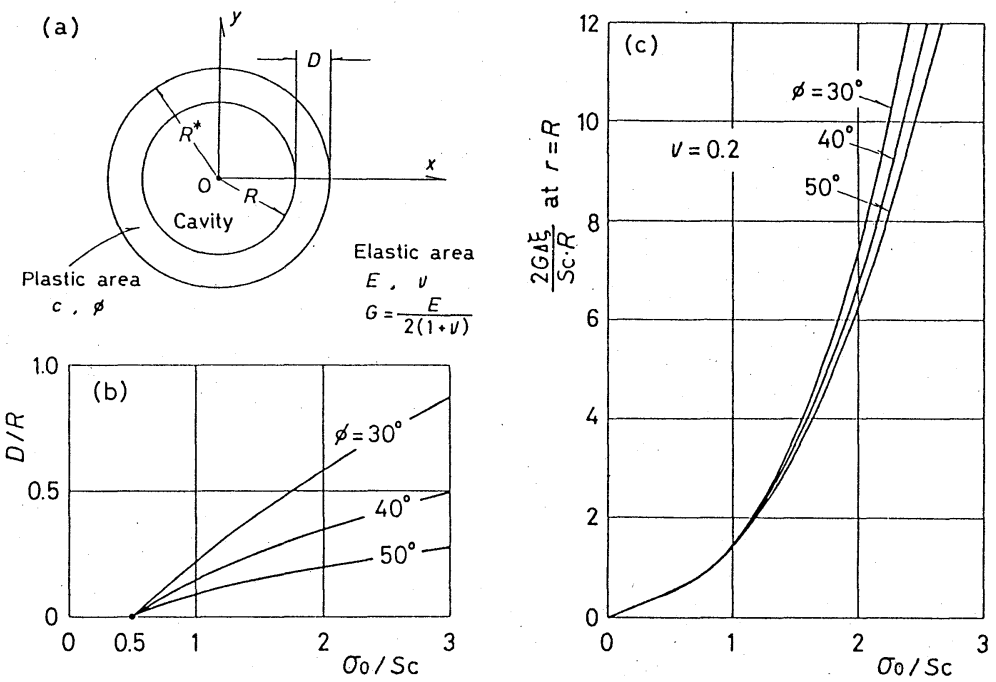

Fig. 3 Elasto-plastic behaviour of circular opening under hydrostatic pressure: (a) ring-shaped plastic area; (b) depth of plastic area versus hydrostatic pressure; (c) radial diaplacement at the surface of circular opening due to the excavation, depending on the intensity of hydrostatic pressure. 


\section{3. 特性曲線法による塑性変形の解析方法}

モール・クーロンの破壊基準(1)式は主応力を用いて，

$\sigma_{1}-\sigma_{3}=2 c \cos \phi+\left(\sigma_{1}+\sigma_{3}\right) \sin \phi$

と書くことができ，モールの応力円表示によると，

$$
\begin{aligned}
f= & \left(\frac{\sigma_{x}-\sigma_{y}}{2}\right)^{2}+\frac{\left(\tau_{x y}\right)^{2}}{2}+\frac{\left(\tau_{y x}\right)^{2}}{2} \\
& -\left(c \cos \phi+\frac{\sigma_{x}+\sigma_{y}}{2} \sin \phi\right)^{2}=0
\end{aligned}
$$

である。ここに, $\sigma_{x}, \sigma_{y}, \tau_{x y}$ および $\tau_{y x}$ は直角座標系 $x, y$ の応力成分である。

さて, 塑性ポテンシャルの理論 ${ }^{3)}$ ( 関連流れ則 ) より塑 性ポテンシャルは破壊曲面 $f=0$ に等しいとし, $x, y$ 座標 系の塑性直ひずみ増分 $d \varepsilon_{x}{ }^{p}, d \varepsilon_{y}{ }^{p}$ およよ゙せん断ひずみ増分 $d r_{x y}^{p}$ をつぎのように仮定しよう。

$$
\begin{aligned}
& d \varepsilon_{x}^{p}=\frac{\partial f}{\partial \sigma_{x}} d \lambda^{*}=d \lambda\left(\frac{\sigma_{x}-\sigma_{y}}{2 T}-\sin \phi\right) \\
& d \varepsilon_{y}^{p}=\frac{\partial f}{\partial \sigma_{y}} d \lambda^{*}=d \lambda\left(\frac{\sigma_{y}-\sigma_{x}}{2 T}-\sin \phi\right) \\
& d \gamma_{x y}^{p}=\frac{\partial f}{\partial \tau_{x y}} d \lambda^{*}=d \lambda \frac{\tau_{x y}}{T}
\end{aligned}
$$

ここに，

$$
T^{2}=\left(\frac{\sigma_{x}-\sigma_{y}}{2}\right)^{2}+\left(\tau_{x y}\right)^{2}=\left(\frac{\sigma_{1}-\sigma_{3}}{2}\right)^{2}
$$

であり, $d \lambda\left(=d \lambda^{*} \cdot T\right)$ の意味は後述する。いま, Fig. 4 (a)のように $x$ 軸と $\sigma_{1}$ 軸のなす角を $\beta$ とすると，

$$
\begin{aligned}
& \sigma_{x}=\frac{1}{2}\left\{\left(\sigma_{1}+\sigma_{3}\right)+\left(\sigma_{1}-\sigma_{3}\right) \cos 2 \beta\right\} \\
& \sigma_{y}=\frac{1}{2}\left\{\left(\sigma_{1}+\sigma_{3}\right)-\left(\sigma_{1}-\sigma_{3}\right) \cos 2 \beta\right\}
\end{aligned}
$$
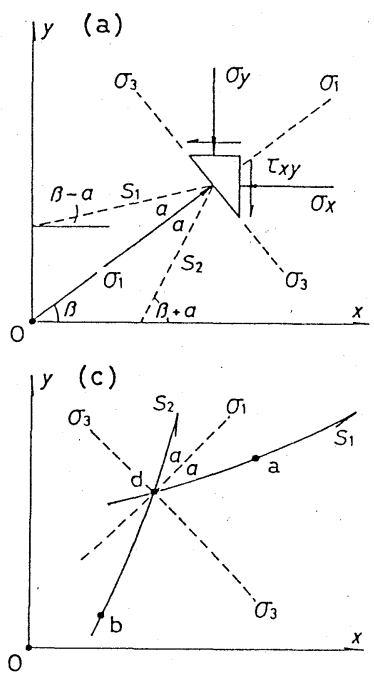

Fig. 4 The method of characteristics for displacement analysis in plastic area: (a) co-ordinates and stress components; (b) displacements along slip lines; (c) slip lines, $S_{1}$ and $S_{2}$, and nodal points a, b and d; (d) displacement analysis based on the continuity of displacement on $\mathrm{r}_{3}$.
であり,

$$
\tau_{x y}=\frac{1}{2}\left(\sigma_{1}-\sigma_{3}\right) \sin 2 \beta
$$

$\sigma_{x}-\sigma_{y}=\left(\sigma_{1}-\sigma_{3}\right) \cos 2 \beta=2 T \cos 2 \beta$ が成立している。したがつて，(21)式は

$$
\begin{aligned}
& d \varepsilon_{x}{ }^{p}=d \lambda(\cos 2 \beta-\sin \phi) \\
& d \varepsilon_{y}{ }^{p}=-d \lambda(\cos 2 \beta+\sin \phi) \\
& d \gamma_{x y}{ }^{p}=d \lambda \sin 2 \beta
\end{aligned}
$$

と表現できる。したがつて, 塑性主びずみの増分 $d \varepsilon_{1}{ }^{p}$ およ び $d \varepsilon_{3}{ }^{p}$ は

$$
\begin{aligned}
& d \varepsilon_{1}^{p}=d \lambda(1-\sin \phi) \\
& d \varepsilon_{3}^{p}=-d \lambda(1+\sin \phi)
\end{aligned}
$$

であり,これより $d \lambda$ は

$$
d \lambda=\frac{d \varepsilon_{1}{ }^{p}-d \varepsilon_{3}{ }^{p}}{2}
$$

なる意味ををつことがわかる。

(25)式からd入を消去すると

$$
\begin{aligned}
& d \varepsilon_{x}{ }^{p}-d \varepsilon_{y}{ }^{p}=2 d \gamma_{x y}{ }^{p} \cot 2 \beta \\
& d \varepsilon_{x}{ }^{p}+d \varepsilon_{y}{ }^{p}=-2 d \gamma_{x y}{ }^{p} \frac{\sin \phi}{\sin 2 \beta}
\end{aligned}
$$

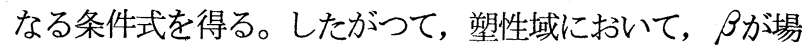
所ごとに一定値をとる場合に限定すると，上式を積分して

$$
\begin{aligned}
& \varepsilon_{x}{ }^{p}-\varepsilon_{y}{ }^{p}=2 \gamma_{x y}{ }^{p} \cot 2 \beta \\
& \varepsilon_{x}{ }^{p}+\varepsilon_{y}{ }^{p}=-2 \gamma_{x y}{ }^{p} \frac{\sin \phi}{\sin 2 \beta}
\end{aligned}
$$

と表記できる。 $\beta$ が場所ごとに一定值をとる場合とは，境 界条件としての壁面の表面力分布が変化せず，塑性状態に おいて主応力方向が変らない場合であり, 壁面がはじめか ら自由面であつて, 無限遠に作用する地圧 $\sigma_{x}^{\infty}, \sigma_{y}^{\infty}$ が単 調に増大する場合や空洞が一瞬に掘削される場合などが考 えられる。反対に境界条件としての壁面の表面力分布が変 化する場合には，これに対応して $\beta$ 変化するので, 解析 は(28)，(29)式に基ついて増分形式で進めねばならない。

一方, $x, y$ 座標系の変位成分を $u, v$ とすると, これら はつぎのように定義できる。

$$
u=u_{0}+\Delta u, v=v_{0}+\Delta v
$$

ここに, $u_{0}, v_{0}$ は初期变位成分, $\Delta u, \Delta v$ は掘削変位成分 である。初期応力を $\sigma_{x}^{\infty}, \sigma_{y}{ }^{\infty}, \tau_{x y}^{\infty}$ とすると,

$$
\begin{aligned}
& 2 G u_{0}=\left\{(1-\nu) \sigma_{x}^{\infty}-\nu \sigma_{y}^{\infty}\right\} x+\tau_{x y}^{\infty} \cdot y \\
& 2 G v_{0}=\left\{-\nu \sigma_{x}^{\infty}+(1-\nu) \sigma_{y}^{\infty}\right\} y+\tau_{x y}^{\infty} \cdot x
\end{aligned}
$$

が成立する。

さて，塑性域のひずみは弾性ひずみと塑性ひずみの和で あり, $x, y$ 座標系の変位成分 $u, v$ によつてつぎのように 定義できるものとする。

$$
\begin{aligned}
& \varepsilon_{x}=\varepsilon_{x}{ }^{e}+\varepsilon_{x}{ }^{p}=\frac{\partial u}{\partial x} \\
& \varepsilon_{y}=\varepsilon_{y}{ }^{e}+\varepsilon_{y}^{p}=\frac{\partial v}{\partial y} \\
& r_{x y}=\gamma_{x y}{ }^{e}+\gamma_{x y}{ }^{p}=\frac{1}{2}\left(\frac{\partial u}{\partial y}+\frac{\partial v}{\partial x}\right)
\end{aligned}
$$


ここで，弾性ひずみは平面ひずみ状態として塑性域の応力 からつぎのように与えられ，塑性ひずみは(30)式に従う。

$$
\begin{aligned}
& 2 G \varepsilon_{x}^{e}=(1-\nu) \sigma_{x}-\nu \sigma_{y} \\
& 2 G \varepsilon_{y}{ }^{e}=-\nu \sigma_{x}+(1-\nu) \sigma_{y} \\
& 2 G \gamma_{x y}{ }^{e}=\tau_{x y}
\end{aligned}
$$

(30)式と(33)式を連立させて塑性ひずみの項を消去すると， つぎの双曲型偏微分方程式が得られる。

$$
\begin{aligned}
& \frac{\partial u}{\partial x}-\cot 2 \beta \frac{\partial u}{\partial y}-\cot 2 \beta \frac{\partial v}{\partial x}-\frac{\partial v}{\partial y}=0 \\
& \frac{\partial u}{\partial x}+\left(\frac{\sin \phi}{\sin 2 \beta}\right) \frac{\partial u}{\partial y}+\left(\frac{\sin \phi}{\sin 2 \beta}\right) \frac{\partial v}{\partial x}+\frac{\partial v}{\partial y}=g
\end{aligned}
$$

ここに,

$$
g=\varepsilon_{x}^{e}+\varepsilon_{y}^{e}+2 \gamma_{x y} \frac{\sin \phi}{\sin 2 \beta}
$$

である。(35式の特性曲線はすべり線に一致し，次式で与え られることが証明できる。

$$
\frac{d y}{d x}=\tan (\beta \pm \alpha), \alpha=\frac{\pi}{4}-\frac{\phi}{2}
$$

すなわち, Fig.4(a)のように, すべり線 $S_{1}$ の傾きは $\beta-\alpha$, すべり線 $S_{2}$ の傾きは $\beta+\alpha$ である。したがつて，つぎの関 係が導ける。

$$
\begin{aligned}
& \cos \phi \frac{\partial}{\partial x}=\sin (\beta+\alpha) \frac{d}{d S_{1}}-\sin (\beta-\alpha) \frac{d}{d S_{2}} \\
& \cos \phi \frac{\partial}{\partial y}=-\cos (\beta+\alpha) \frac{d}{d S_{1}}+\cos (\beta-\alpha) \frac{d}{d S_{2}}
\end{aligned}
$$

また，すべり線方向の変位成分をFig.4(b)のように $W_{1}$ お よび $W_{2}$ とすると，

$$
\begin{aligned}
& u=W_{1} \cos (\beta-\alpha)+W_{2} \cos (\beta+\alpha) \\
& v=W_{1} \sin (\beta-\alpha)+W_{2} \sin (\beta+\alpha)
\end{aligned}
$$

が成立する。

(38)式と39)式を用いて，35式を書き換えると，す べり線上で成立する $W_{1}$ および $W_{2}$ に関する微分 方程式がつぎのように与えられる。

$$
\begin{aligned}
& \frac{d W_{1}}{d S_{1}}+\sin \phi \frac{d W_{2}}{d S_{1}}-\cos \phi \cdot W_{2} \frac{d \beta}{d S_{1}}=\frac{g}{2} \\
& \frac{d W_{2}}{d S_{2}}+\sin \phi \frac{d W_{1}}{d S_{2}}+\cos \phi \cdot W_{1} \frac{d \beta}{d S_{2}}=\frac{g}{2}
\end{aligned}
$$

Fig.4(c)のように差分点 a， b およびdを設け ると，(40)式はつぎのような差分近似式に置き換え られる。

$$
\begin{aligned}
& \left(W_{1 \mathrm{a}}-W_{1 \mathrm{~d}}\right)+\sin \phi\left(W_{2 \mathrm{a}}-W_{2 \mathrm{~d}}\right) \\
& -\cos \phi\left(\frac{W_{2 \mathrm{a}}+W_{2 \mathrm{~d}}}{2}\right)\left(\beta_{\mathrm{a}}-\beta_{\mathrm{d}}\right)=\frac{g_{\mathrm{a}}+g_{\mathrm{d}}}{4} \widehat{\mathrm{ad}} \\
& \left(W_{2 \mathrm{~d}}-W_{2 \mathrm{~b}}\right)+\sin \phi\left(W_{1 \mathrm{~d}}-W_{1 \mathrm{~b}}\right) \\
& +\cos \phi\left(\frac{W_{1 \mathrm{~d}}+W_{1 \mathrm{~b}}}{2}\right)\left(\beta_{\mathrm{d}}-\beta_{\mathrm{b}}\right)=\frac{g_{\mathrm{d}}+g_{\mathrm{b}}}{4} \widehat{\mathrm{db}} \\
& \ldots \ldots \ldots \cdots \cdots(11)
\end{aligned}
$$

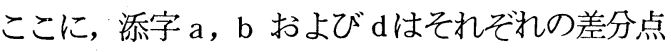

における值を示し， 合 およびする したがつて, $\mathrm{a}$ 点および $\mathrm{b}$ 点の変位場を既知とすると, 上 式は $\mathrm{d}$ 点の変位 $W_{1 \mathrm{~d}}, W_{2 \mathrm{~d}}$ に関する連立一次方程式である。 結局, Fig.4(d)に示す塑性域の変位場は, 弾塑性境界の $\Gamma_{3}$ 上の弾性域変位を境界条件として, (41)式に基ついて数値 解析できることになる。

\section{2 軸応力下の円形空洞の弾塑性変形}

前節の数值解析法を用いて, 2 軸応力下の円形空洞の弾 塑性変形を解析し，その特徵を分析する。ただし，岩盤の ポアソン比レを 0.2 とする。また, 初期応力状態は $\tau_{x y}{ }^{\infty}=$ $0, \sigma_{y}^{\infty} \geqq \sigma_{x}^{\infty}$ であると仮定し, 第 1 報と同様に, 無次元比 $n=\sigma_{y}^{\infty} / S c$ および側圧比 $m=\sigma_{x}^{\infty} / \sigma_{y}^{\infty}$ を用いて表示する。 壁面上の掘削変位はFig.5に例示するように塑性域の形 およびその大きさに依存する。Fig.5 では, 壁面変形の弾 塑性解と完全弾性解とが比較されており, 塑性域は黒叙り の部分である。側圧比 $m=1$, すなわち静水圧下ではFig.5 (a)のように, リング状の塑性域が生じ, 壁面は軸対称に変 形する。一方, $m=0.5$ の 2 軸応力下では, Fig. 5 (b)および (c)に示すように, $n$ の増大とともに塑性域は部分圧縮降伏型 から全周圧縮降伏型へと変化し, 左右の壁面における内空 変位が著しく増大する。これは，塑性域において引張の塑 性びずみ $\varepsilon_{r}{ }^{p}$ が急増するためである。

2 軸応力下の円形空洞について, 塑性域の奥行き $L$ の分 布および壁面上の半径方向掘削変位 $\Delta \xi$ の分布を例示する とFig.6のようである。Fig.6(a)より側圧比 $m=0.5$ の場 合には $n=0.4$ まで壁面はすべて弾性状態にあり, $n \doteqdot 2.0$ を境として部分型の圧縮降伏から全周型の圧縮降伏に移行 すること, また, 塑性域の奥行き $L$ は $n$ の増加とともに単

(a) $m=\sigma_{x}^{\infty} / \sigma_{y}^{\infty}=1.0, n=\sigma_{y}^{\infty} / \mathrm{Sc}=2.5, \quad$ (b) $m=\sigma_{x}^{\infty} / \sigma_{y}^{\infty}=0.5, n=\sigma_{y}^{\infty} / \mathrm{Sc}=1.0$, $\phi=40^{\circ}(q=4.6)$

$$
\phi=40^{\circ}(q=4.6)
$$

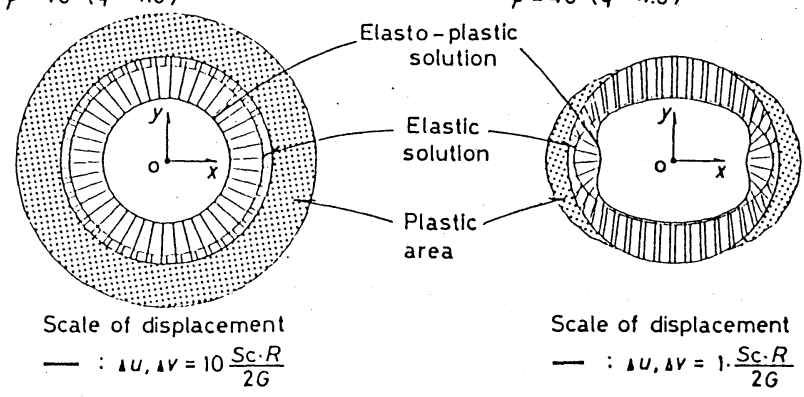

(c) $m=\sigma_{x}^{\infty} / \sigma_{y}^{\infty}=0.5, n=\sigma_{y}^{\infty} / S c=2.5$,

$\phi=40^{\circ}(q=4.6)$

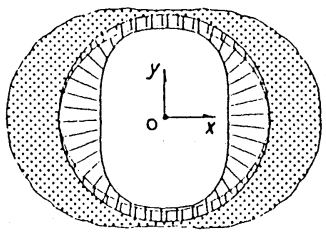

Fig. 5 Elasto-plastic deformation of circular opening, comparing with the elastic solution.
Scale of displacement - $: \Delta u, \Delta v=10 \frac{S c \cdot R}{2 G}$ 
2 軸応力下の円形空洞の弾塑性変形 $\square$

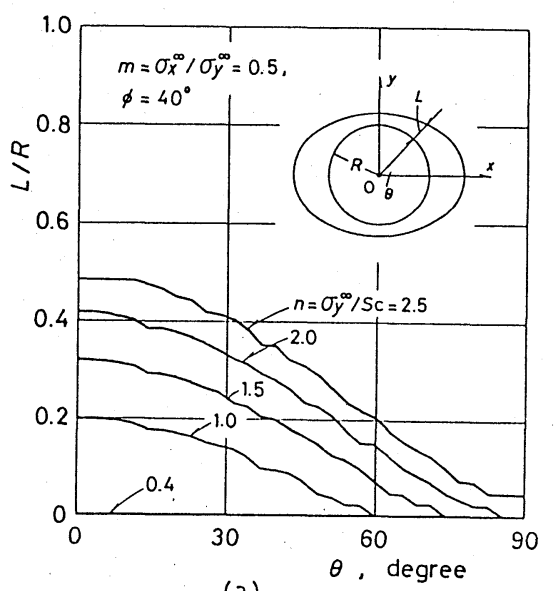

(a)

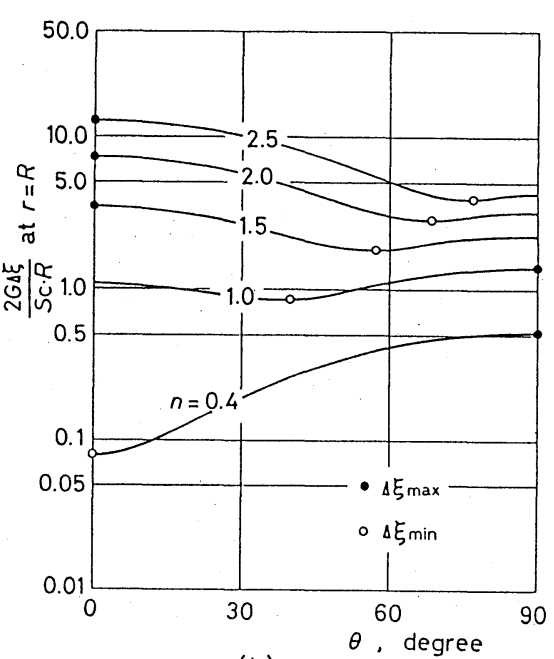

(b)

$$
\begin{aligned}
& \frac{2 G \Delta \xi_{\max }}{S c R}=\{(1-\nu)(2-m) \\
& \left.\quad+\nu_{m}\right\} n \quad \cdots \cdots \cdots(42)
\end{aligned}
$$

を示している。Fig.7 に示した $=30^{\circ}, 40^{\circ}$ および $50^{\circ}$ の 3 例を比 較して, $\Delta \xi_{\text {max }}$ に対する $\phi$ 影響 が小さく, かつ, 側圧比による $\Delta \xi_{\max }$ の差違がそしいことに注 目される。

側圧比 $m=1$ の数值解析結果 ( 図中の黒丸 ) は $n=0.5$ まで $m$ $=1$ の破線に一致し, $n>0.5$ では (19)式から求めた太実線に一致して いる。したがつて, 数值解析の精 度は満足できるものであると考元 られる。一方, $m=0.75$ の場合

調に増大することが読みとれる。このような塑性域の単調 な形状変化は円形空洞の著しい特徵である。

Fig.6(b)では, 壁面上の最大掘削変位 $\Delta \xi_{\max }$ を黒丸で, 最小掘削変位 $\Delta \xi \min$ を白丸でそれぞれ示した。 $n=0.4$ と 1.0 では $\theta=90^{\circ}$ で $\Delta \xi$ は最大值をとり, $n \geqq 1.5$ では $\theta=0^{\circ}$ で最大值をとる。一方, 最小掘削変位の生じる位置 の回転角 $\theta$ は $n$ の増加とともに増大し, $90^{\circ}$ に漸近する。

Fig.6において塑性壁面上の 1 点に着目すると， $\Delta \xi$ は その点から計つた塑性域の奥行き $L に$ 比例して増加する。 また, 塑性域の奥行き $L$ 異なる壁面上の 2 点で $\Delta \xi$ を比

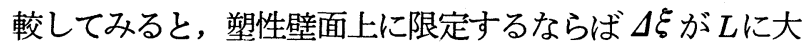
略比例することが見出せる。前者の比例関係はすべての弾 塑性変位場に共通して成立する。しかし, 後者の比例関係 は円形空洞のように壁面の曲率半径が一定である場合にだ け成立する関係と考えられる。

最大掘削変位 $\Delta \xi \max$ と無次元比 $n=\sigma_{y}^{\infty} / S c$ の関係を 両対数紙上にまとめると, Fig.7のようである。同図中の 太実線は(19)式から求めた関係であり, 破線は完全弾性解か ら求められる関係 ${ }^{4)}$
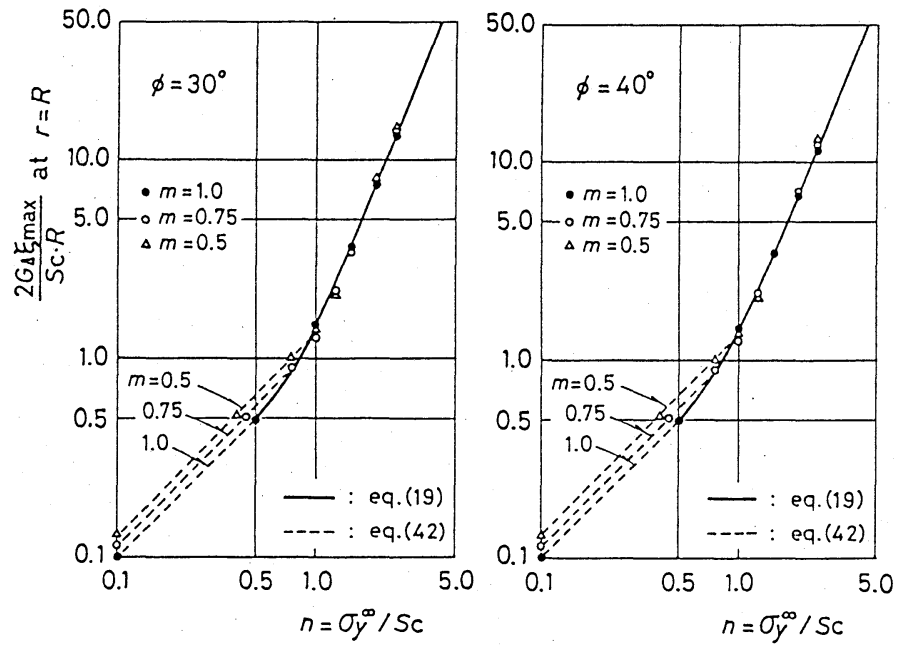

（図中の白丸 ) は $n=0.75$ まで $m=0.75$ の破線に一致し, $n>0.75$ では太実線にほぼ一致する值を示している。また， $m=0.5$ の場合 ( 図中の三角) は $n=1.0$ まで $m=0.5$ の破

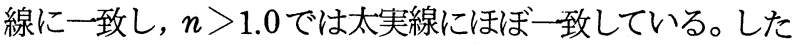
がつて, 円形空洞壁面上の最大掘削変位 $\Delta \xi_{\max }$ は(42)式と (19)式とを用いて予想できると考えられる。すなわち，弾性 状態の $\Delta \xi_{\text {max }}$ は442式によつて予想できる。一方, $n>0.5$ の場合には(19)式の静水圧 $\sigma_{0}$ に初期主応力の最大值 $\sigma_{y}^{\infty}$ を代 入して弾塑性状態の $\Delta \xi$ を求め，これを(42)式による弾性解 の $\Delta \xi_{\max }$ と比較して, 大きい方の值を採用すれば良いと考 えられる。

\section{5. 結言}

岩盤の降伏条件としてモール・クーロンの破壊基準を採 用し，関連流れ則に基づき塑性ポテンシャルが破壊曲面に 等しい場合について地下空洞まわりの変位場を解析する方 法を提案するとともに，円形空洞を例にとりその弾塑性挙 動について詳論した。

はじめに, 静水圧下の円形空洞の軸対称変形に対する解

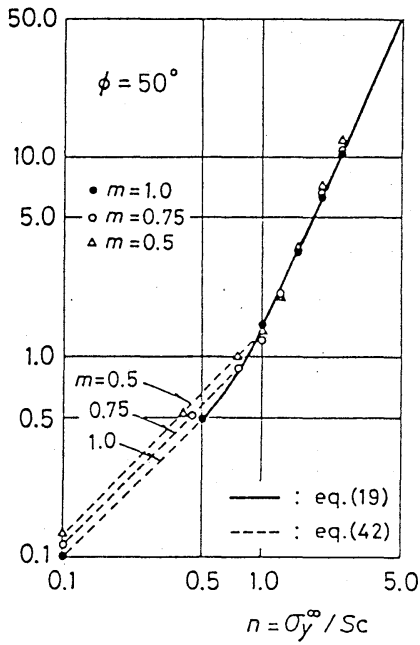

Fig. 7

Maximum radial displacement at the surface of circular opening versus the intensity of

vertical stress. 
析解として(18)式を与え，内空変位に関する主要な支配因子 が地圧強度比 (静水圧と 1 軸圧縮強度の比 ) であり, 内部 摩擦角の影響は少ないことを論じた。

つぎに， 2 軸応力下の塑性域变位場を特性曲線法によつ て数值解析する方法を提案した。ただし，本論文では空洞 が一瞬に開削された場合の最終変形状態および既設空洞ま わりの地圧が単調に増加する場合の変位場を数值解析する 方法を中心に論じ，逐次掘削時の挙動に関しては増分形式 の解析が必要であることを指摘するに止めた。

側圧比が $1 / 3$ より大きい初期応力状態における塑性域は 第 1 報て論じたように，地圧の増大とともに部分圧縮降伏 型から全周圧縮降伏型へと変化する。このとき円形空洞で は塑性域の奥行きが地压の増大とともに比較的単調に増大 するという特徵のあることを指摘した。また，塑性壁面上 の任意点の半径方向変位がその点に㧈ける塑性域の奥行き にほぼ比例することを示し，この原因が塑性域におけるダ イレイタンシーによることを指摘した。
円形空洞の弾塑性挙動の著しい特徵として, 壁面上の最 大変位に対して側圧比の影響が少なく，2軸応力下の最大 掘削変位は初期応力の最大主応力が静水圧的に作用する場 合のそれにほぼ等しいことを見出した。この関係は，第 1 報で論じられた塑性域の最大奥行きに関する法則性，すな わち， 2 軸応力下の塑性域の最大奥行きは初期応力の最大 主応力が静水圧的に作用する場合のそれにほぼ等しいとい う関係とともに，ロックボルトなどの支保設計に有用な知 見であると考えられる。

$$
\text { 参 考 文 献 }
$$

1）菅原勝彦・青木俊朗・鈴木康正：2軸応力下の空洞まわりの弾塑性 応力解析一境界要素 ·特性曲線結合法による岩盤空洞の弾塑性解析 （第 1 報 ），日本鉱業会誌，104，1203，pp·261～266，(1988）

2) J.C.Jaeger and N.G.W.Cook : Fundamentals of Rock Mechanics, Chapman and Hall, London, pp.134 137 and $\mathrm{pp} \cdot 414 \sim 424,(1969)$

3) Y.C.フ フン著, 大橋義夫, 村上澄男, 神谷紀生共訳 : 固体の力学 /理論, 培風館, 東京, pp. 144, (1970)

4）たとえば鈴木 光 : 岩盤力学と計測, 内田老鶴圃, 東京, $\mathrm{pp} .172$ $\sim 176$, (1973)

\section{Elasto-plastic Deformation of a Circular Opening under Bi-axial Stress Condition}

_ Elasto-plastic analysis of rock caverns by a coupled Boundary Element-Characteristics method (2nd Report) —_

by Toshiro AOKI ${ }^{1}$, Katsuhiko SUGAWARA ${ }^{2}$, Yuzo OBARA $^{3}$ and Yasumasa SUZUKI ${ }^{4}$

Elasto-plastic deformation of a circular opening under bi-axial stress condition has been analyzed on the basis of the theory of plastic potential. The plastic area surrounding the opening has been analyzed by the coupling method of the boundary element method and the characteristics method, presented in the first report. To evaluate the elasto-plastic displacement in the plastic area, the method of characteristics has been successfully applied, and the Mohr-Coulomb's failure criterion is adopted for the plastic potential.

Hydrostatic pressure problem has been firstly discussed, and it is noted that the radial displacement at the inner surface of a circular opening is mainly depending upon the ratio of hydrostatic pressure to the uniaxial compressive strength of rock, and the influence of the coefficient of internal friction is comparatively small when the associated flow rule is applicable. Moreover, the present numerical analysis has been compared with the analytical solution and proved effective.

For the bi-axial stress condition that the ratio of initial principal stresses is greater than $1 / 3$, it is made clear that the partial yielding around a circular opening proceeds to the yielding of whole surface with increase of initial stress. By analyzing the relationship among the intensity of initial stress, the depth of plastic area and the elasto-plastic displacement at the inner surface, it has been concluded that the maximum surface displacement due to the excavation is not affected very much by the ratio of initial principal stresses and can be evaluated from the analytical solution under hydrostatic pressure condition.

1. Engineer, Tokyu Construction Co., Ltd.

3. Lecturer, Dr., Kumamoto University.
2. Prof., Dr., Kumamoto University. 4. Engineer, Tokyo Electric Power Services. 